\title{
GOUT IN THE TIME AND PERSON OF GEORGE IV:
}

\section{A CASE HISTORY*}

\author{
BY \\ E. G. L. BYWATERS \\ From the Rheumatism Research Unit (M.R.C.), Taplow, and the Department of Medicine, \\ Postgraduate Medical School of London, Hammersmith
}

The early 19th century was the springtime, or heyday, of gout: tophi like crocuses were bursting everywhere, and "the Honour of the Gout" (Misaurus, 1720) was as much a status symbol as a nuclear bomb shelter is now. Every good gouty family had one ancestor who could write on the blackboard with his tophi, even if he were no schoolmaster. The diet of the upper classes in those days was largely protein and port. Even John Bull in poverty is portrayed with his steak and porter, vis-à-vis his French revolutionary counterpart "living in luxury" on roots. Rheumatic fever must have been far more frequent but, as always, it affected mainly the Dispensary patients (and there was no National Health Service). Gout traditionally affects the wealthy and eminent, and the literature of the time reflects the interests of the physicians. For every 18th- and 19th-century book on rheumatism, there are ten on gout, allowing for some combining the two.

Furthermore, this was a disease whose abnormal chemical manifestations literally thrust themselves out ("like crab's eyes", to quote Sydenham, 1749) under the eyes of the physician, at a time when the new science of chemistry was developing prescient links with the older discipline of medicine. Lavoisier, decapitated in 1794 because the new French Republic had no need of savants, had destroyed the phlogistom theory and laid the basis for the atomic age, brought in by Dr. Dalton in 1808. The old alchemical myths were giving way to the surer foundations of chemistry as we know it to-day: in the late 18th century the whole field lay open to the pioneer.

\footnotetext{
* Based on a communication to the Heberden Society meeting in Brighton in May, 1962.
}

One of the first of these was Scheele (1742-1786), a Swedish apothecary who, when his shop blinds were drawn, got down to what we would now call "basic research". Besides valuable contributions to methodology and the discovery of most of the aliphatic organic acids, he isolated uric acid, or acidum concretum as he called it, from a urinary calculus about 1776 , in his thirties, before he himself died of "rheumatism" at the early age of 44 .

In 1797, William Hyde Wollaston isolated the same material from a gouty tophus. He had been preceded, conjecturally at least, by Murray Forbes (1793). Wollaston was a doctor and a Fellow of Caius, who (oddly as a nephew of Heberden but fortunately for science) failed to get a place on the staff at St. George's. He gave up medicine and turned to the whole field of science, which at that time men could still do. During his 62 years of life he ranged from the discovery of palladium and rhodium to theories of vision and the origin of fairy rings: in 1802 he discovered those dark bands in the spectrum later called Fraunhofer lines. He died in 1828, 2 years before George IV, having seen Dalton in 1808, and Avogadro in 1811, lay the cornerstones of modern chemical science. At the same time practical medicine carried on with its empirical cures and mediaeval logic. But even here, although there were no double-blind controlled trials, the scientific ambience was beginning to tell: Haygarth (1805), for instance, detailed the effects of Peruvian bark in acute rheumatism, both in statistical form and with due regard for criteria of diagnosis and improvement.

This was the scientific background against which our hero the Prince Regent developed his gout, and although the chemical discoveries only bore fruit, from the point of view of the patient, in 1948, with caronamide as a by-product of penicillin research 
(Wolfson) (i.e. 150 years after the incrimination of uric acid in gout by Wollaston and 100 years after the demonstration of hyperuricaemia by Alfred Garrod in 1848), George IV was greatly helped during his 19 years of gouty existence by an empirical discovery of practical clinical medicine, that of Colchicum autumnale, to which we shall return. But first we must provide the genetic and environmental background for this most distinguished patient and his clinical history.

\section{Family History}

Neither his father nor mother had gout, and this is scarcely surprising, because they were both thrifty and, indeed, parsimonious: the first model Hanoverians-"Farmer George". Their fifteen children, however, included five with gout: four out of the seven sons who reached adult life and a daughter. Besides the first-born, George, Prince of Wales, gout afflicted William, Duke of Clarence, as early as 1823 (Leveson Gower, 1894); after his accession as William IV, the Sailor King was unable to make his first official review of the Guards on horseback because of the chalkstones in his hands - caricatured by Doyle in 1831. Frederick, Duke of York, was also said to have gout (Croker Papers, ed. Jennings, 1884). Adolphus, Duke of Cambridge, the virtuous son whose environmental background was different enough to warrant a belief in heredity, was ordered to England in 1822 to take sea bathing for his gout and was confined with gout at the time of the birth of his second daughter (Fulford, 1933). Finally, Princess Augusta (1768-1840) had gout (Jerningham Letters, ed. Castle, 1896).

Since gout in a female should be fully documented, we quote her brother, the Duke of Cumberland, writing to Lady Frances Shelley from Brighton on January 6, 1831: "My sister, Augusta, has recovered her gout but is not out for she is tender on her foot ... after witnessing what dear Augusta has suffered I cannot conceive how people can be rejoiced to have the complaint" (Shelley, ed. Edgcumbe, 1913). Yet the days of this royal and gouty brood were not shortened. Excluding the three youngest, who died at the age of 4,2 , and 27 respectively, the remaining dozen survived to a mean age of 69 years, and those five sibs who had overt gout lived to $68,64,72,72$, and 76 years respectively.

Our hero, George Augustus Frederick, who was born in 1762 and died in 1830 at the age of 68, was fortunate enough from the historian's viewpoint to live in a period when everyone wrote memoirs and diaries and interminable letters: with no telephone or television, what else was there to do?
From the historical viewpoint, no patient has been so fully, lavishly, and fiendishly documented: from the scientific viewpoint he lived through an age o. which saw a revolution in thought about medicine and chemistry.

\section{The First Attack}

Of prime interest is Fig. 1 (opposite), a print found $\stackrel{\mathbb{}}{\varrho}$ in New York, which antedates any mention of gout; $;$ it depicts the after-results of a party at Oatlands, the $\vec{\circ}$ Duke of York's seat at Weybridge in Surrey, on:November 13, 1811, where the Prince Regent (as he $\vec{\omega}$ now was, since his father's second loss of sanity) suffered an accident and hurt his ankle. This waso no ordinary sprain, however, although it wasi regarded so at the time. Red and exquisitely $\overrightarrow{+}$ painful, it kept him in bed on 1,200 drops of laudanum a day for a fortnight. The physician, $\mathrm{T}$ an obvious Scotsman (doctors being, even at that time, one of Scotland's major exports) is probably Sir Walter Farquhar. He told Lady Melbourne, on November 21, 1811, that the Regent had "broke a tendon in his foot with such violence that he fell? and his leg instantly swelled up to the knee as large⿻日乚 as a man's body, that the inflammation is considerable" (Leveson Gower, 1916).

It is now well known how frequently the first attack of gout follows trauma and is mistaken foro a severe sprain. Various contemporary versions are current, all more or less scandalous, of how this happened, but the truth is probably that the Prince Regent, showing his daughter, Charlotte, $\stackrel{\mathbb{Q}}{2}$ the Highland Fling, slipped and fell. It was also $\overrightarrow{\overrightarrow{0}}$ put about, perhaps by the Duke of Cumberland, 3 that this was a manifestation of his father's trouble (Letters of Princess Charlotte, ed. Aspinall, 1949), hence the allusion to the straight waistcoat which Sir Everard Home, at the end of the bed, is making? and the anxiety manifested by John Bull. Another 3 reason, perhaps, for his prolonged indisposition was the difficulty the Prince was having with his윽 erstwhile friends, the opposition Whigs, who had high hopes of office when the Regency started, but? were disappointed by the Regent, who continued $\$$ Perceval and the Tories in office. The cartoonists often had little regard for, or perhaps even less $N$ knowledge of, the truth, and although Mrs. Fitzherbert, whom he had married in 1785, is attending him, he had already left her twice and had $\omega$ transferred his attentions to the Marchioness of Hertford, a true-blue Tory and, like most of hise inamorata, a grandmother. The Prince, forced by his father into the arms of the Whigs, had been? brought up by Charles James Fox and by Sheridan, 


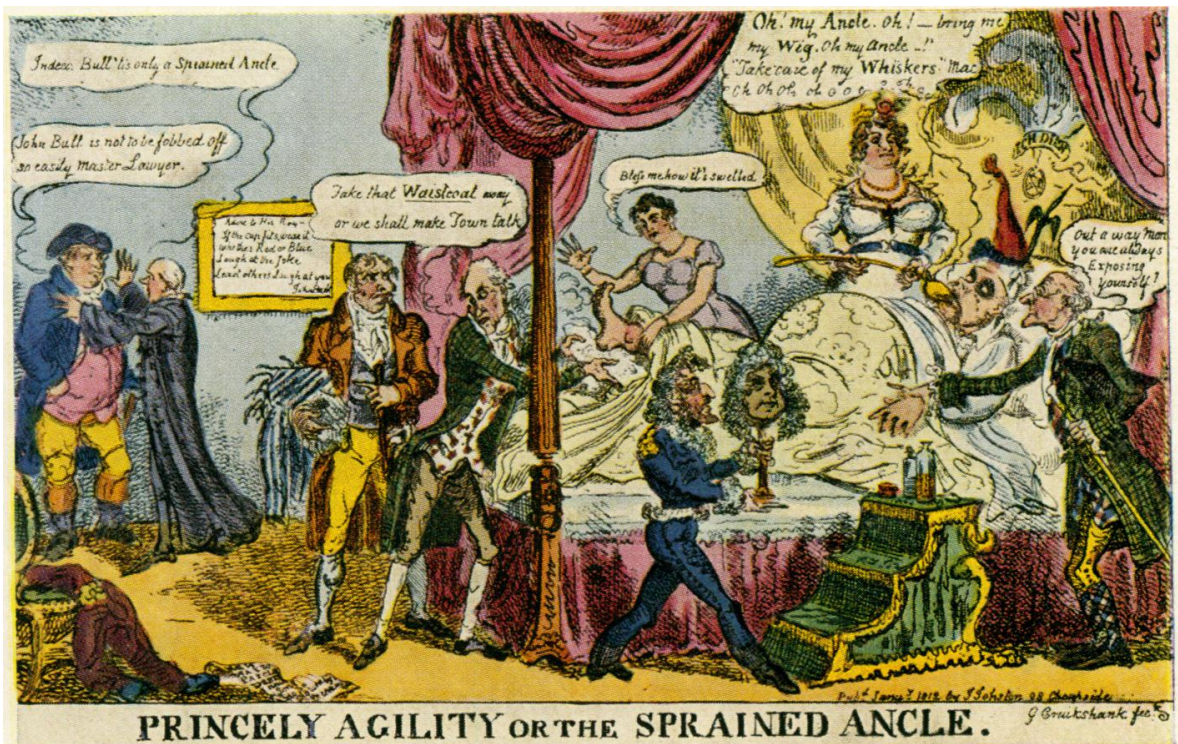

Fig. 1-PRINCELY AGILITY or the SPRAINED ANCLE.

(B.M. 11841. G. Cruikshank, January, 1812.)

L. to R.: John Bull, Perceval, flunkey, Everard Home ("Take that Waistcoat away or we shall make Town talk"), McMahon, Princess Charlotte ("Blefs me how it's swelled"), Mrs. Fitzherbert, the Prince Regent, and Sir Walter Farquhar (“Out a way Mon you are always Exposing yourself!").

This is the aftermath of a sprain sustained at Oatlands, the Duke of York's seat, on November 13, 1811.

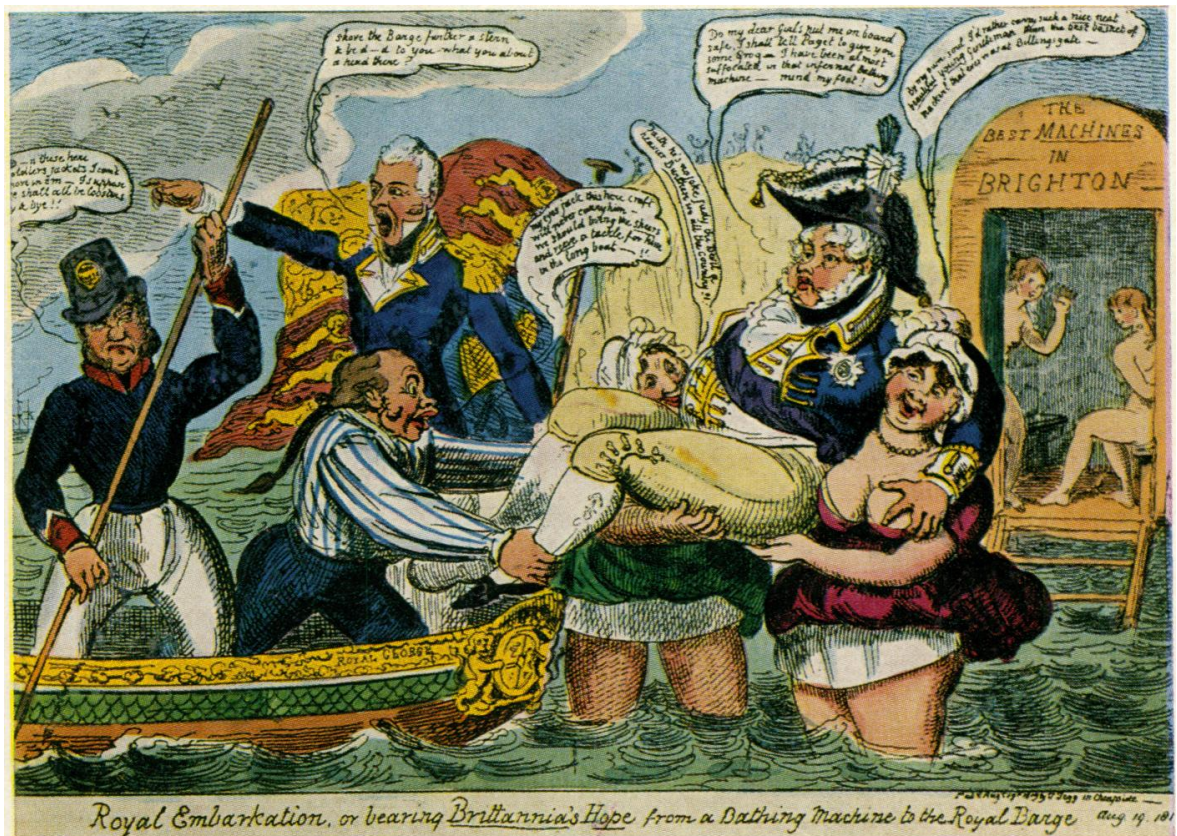

Fig. 9.-Royal Embarkation, or bearing Britannia's Hope from a Bathing Machine to the Royal Barge.

(B.M. 13259. G. Cruikshank, August 19, 1819.)

The Prince Regent left Brighton on August 7, 1819, for his first visit to Cowes Regatta. “Mind my foot!" says George

[ facing p. 326 
not only politically but in other ways, but Fox had (not surprisingly) died of dropsy in 1806, and the Prince trusted no one else of the Whig party. This episode appears to be his first attack of gout, and it lasted a long time. By December 18, 1811, it was said that the Prince had been very bad, with pains in his arms and fingers, and for a time the loss of all power in them (Buckingham Memoirs, 1856). By July, 1812, by which time the Napoleonic Wars had passed their turning point in Wellington's Peninsular campaign, the Prince Regent was still prevented from writing "without considerable pain and difficulty" and his mother wrote in December, 1812 , that she was "sorry the gout still continues to pain you" (Letters, ed. Aspinall, 1938).

The cartoonists, however, did not get round to the gout until later, and in 1813 (Fig. 2) we see a print commemorating the famous expedition into the vaults of Windsor Castle by the Prince Regent, accompanied by McMahon, Yarmouth, and Sir Henry Halford (the Prince's physician, and for 24 years President of the Royal College of Physicians). Halford is holding up Charles's head, which was found severed through the fourth cervical vertebra, and Yarmouth, Hertford's son, known as Red Herrings on account of his hair, is inspecting the coffin of Henry VIII (see Munk, 1895).

This gruesome episode gave rise to Byron's famous lines:
"Famed for contemptuous breach of sacred ties, By headless Charles see heartless Henry lies; Between them stands another sceptred thing- It moves, it reigns-in all but name a king!
Charles to his people, Henry to his wife, - In him the double tyrant starts to life; Justice and Death have mixed their dust in vain, Each royal Vampire wakes to life again.
Ah, what can tombs avail! since these disgorge The blood and dust of both to mould a George."

In this cartoon, however, there is no hint of gout. The disease is first seen in a print of April 1, 1814, published just before the fall of Paris and the abdication of Napoleon (Fig. 3, overleaf). The Prince is depicted tormented by devils, respectively devoted to the gout, the vapours, and the dropsy, attended

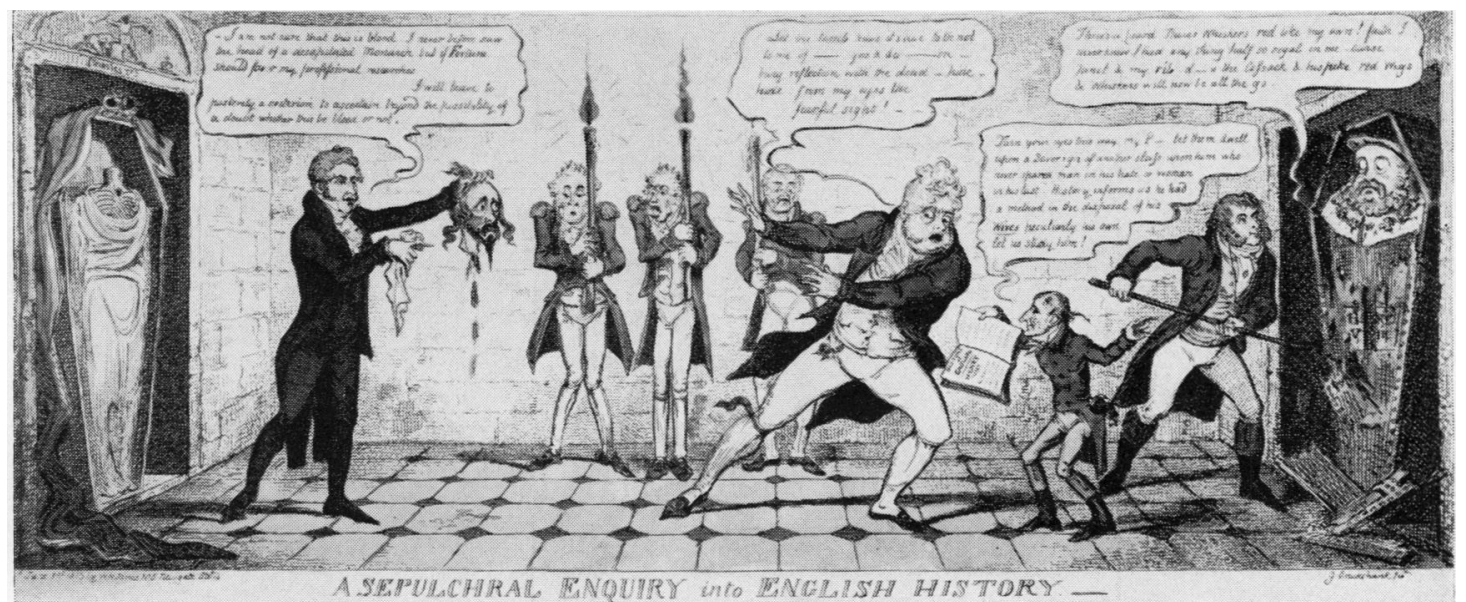

Fig. 2.-A SEPULCHRAL ENQUIRY into ENGLISH HISTORY-.

(B.M. 12056. G. Cruikshank, June, 1813.)

L. to R.: Sir Henry Halford holding Charles's head, three flunkeys, the Prince Regent, McMahon (“" . . a Sovereign of another clafs ... who never spared man in his hate or woman in his lust. History informs us he had a method in the disposal of his Wives peculiarly his own, let us study him!'), Lord Yarmouth, and Henry VIII.

A good likeness of Halford, President of the Royal College for 24 years and physician to four monarchs, appointed to the Regent in 1810. (See his "Life" by William Munk, 1895.) 
by Lady Hertford, and badgered by Sidmouth, Liverpool, Yarmouth, wig-makers, coat-makers, and Sylvester, the Recorder of the City of London, carrying a load of death sentences for felons who had stolen food. This was the year of Napoleon's exile to Elba. The Prince Regent played an important part in the restoration of the gouty Bourbon, Louis XVIII, to the throne of France, and John Bull looked forward to peace, prosperity, and more gout; the Prince Regent is optimistically depicted by the cartoonist making life easier, cheaper, and more pleasant for long-suffering John Bull, while Napoleon broods on Elba. But Napoleon escaped with the violets, to be finally crushed at Waterloo in 1815 .

As in more recent times, the victors, without the excuse of recapitalization, came off second best, and by 1816 the post-war economic crisis was in full swing; as so often before and since, victory brought in its train unemployment, high prices, and scarcity.
The Prince and his Government were attacked for their extravagance and expenditure, particular on the army. Fig. 4 (opposite) depicts the Regent gouty hand, representing the army estimates. Sidmouth, called "the Dr." for the inadequate reason that his father was one, is standing on his pestle and mortar, looking for a speedy remedy to the spreading size of army expenditure, supported by Wellington. Castlereagh is imploring Vansitta to levy more taxes to satisfy the cursed gout, whereass John Bull on the other side says that all that is necessary is to take away the corruption.

The Property Tax, the forerunner of Income Tax $\overrightarrow{\mathrm{C}_{\vec{S}}}$ which the Government wished to continue to pas for the army, was thrown out, and Fig. 5 (opposite shows the Privy Council, sitting heavily on privies (the traditional seat of thought), trying to devise substitutes for it. Castlereagh, Ellenborough, Eldo $\overrightarrow{b_{0}}$ the gouty Regent, McMahon, and Vansittart aEt uttering various scatological puns.

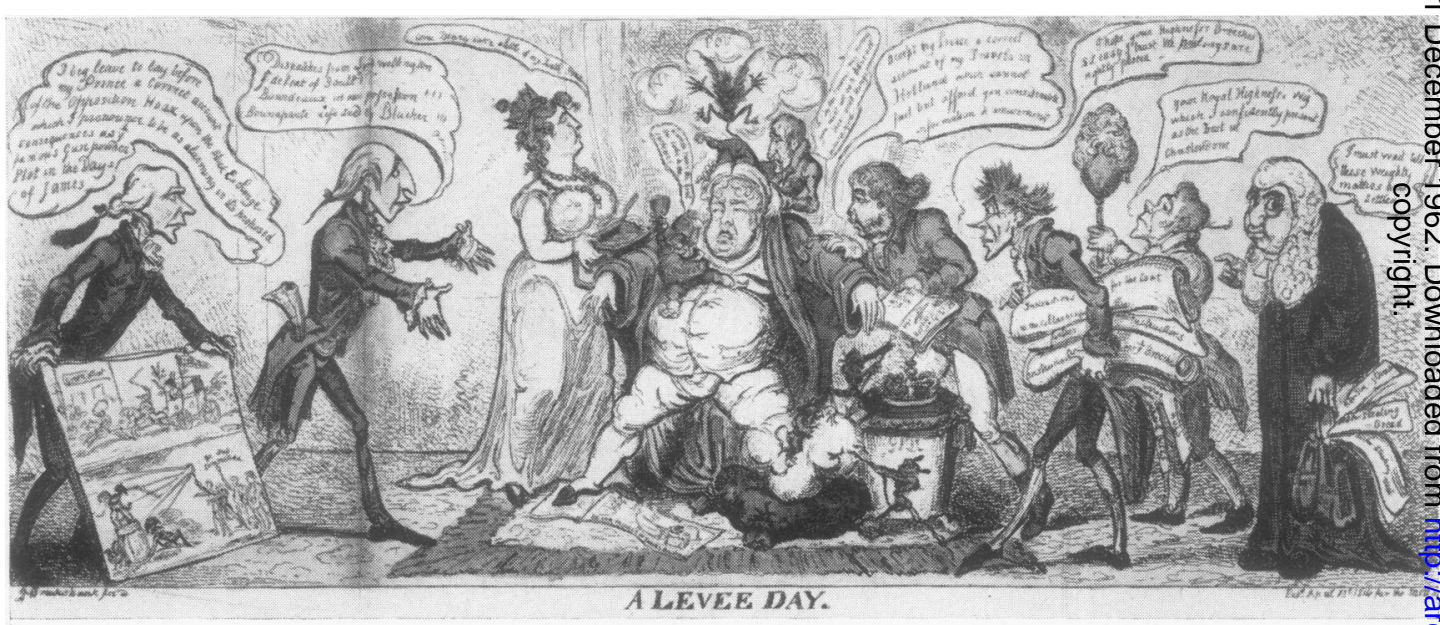

Fig. 3.-A LEVEE DAY.

(B.M. 12208. G. Cruikshank, April 1, 1814.)

L. to R.: Sidmouth, Liverpool, Lady Hertford, the Prince Regent and attendant devils of the gout, of dropsy, and of the vapours, McMahon, Yarmouth, a tailor, a wigmaker, and Sylvester (Recorder of London) with death warrants.

Fig 4.-CONSULTATION on the best CURE for the GOUT.

(B.M. 12805. Lithograph, 1816.)

L. to R.: A sailor; John Bull, the Prince Regent, Wellington, Sidmouth (standing on his mortar and with a clyster pipe hanging from his pocket), Castlereagh, and Vansittart.

Expenditure on the army is depicted as the Regent's gouty L. hand: his R. hand, labelled Navy, is normal size. As John Bull says, " . . . if you take away the CORRUPTION you may reduce it to its natural size with safety".

Fig. 5.-The PRIVY Council, or NECESSARY arrangements to supply a substitute for the PROPERTY TAX!!! (B.M. 12757. G. Cruikshank, March, 1816.)

L. to R.: Each on his own privy privy, Castlereagh ("The Expence of restoring the Bourbons \& keeping them on the Throne has given us the GRIPES \& brought us to a Stool-of repentance! The People (with their usual ignorance \& impatience) say there is a terrible Looseness in our Operations \& that we are Privy to the present Disorders in the Intestines of France- our Bowels are too tender to bear such insinuations without great pain $\mathrm{Oh}$ !-Oh!-Oh!-Oh!'), Ellenborough, Eldon, the Prince Regent, McMahon, and Vansittart.

Scatological puns after the style of the Victoria Palace on the abolition of the Property Tax, with the Prince Regent's gouty leg resting on a cushion. 


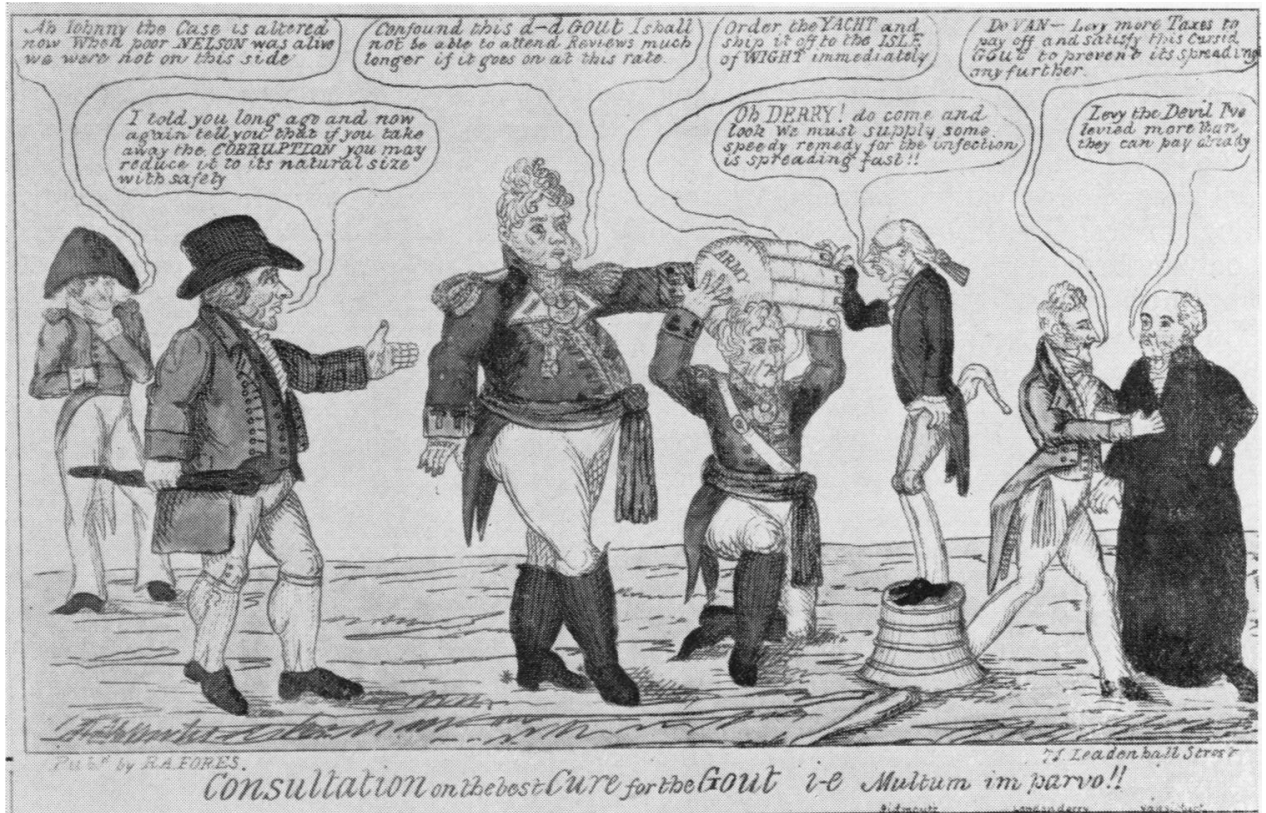

Fig. 4. See legend opposite.

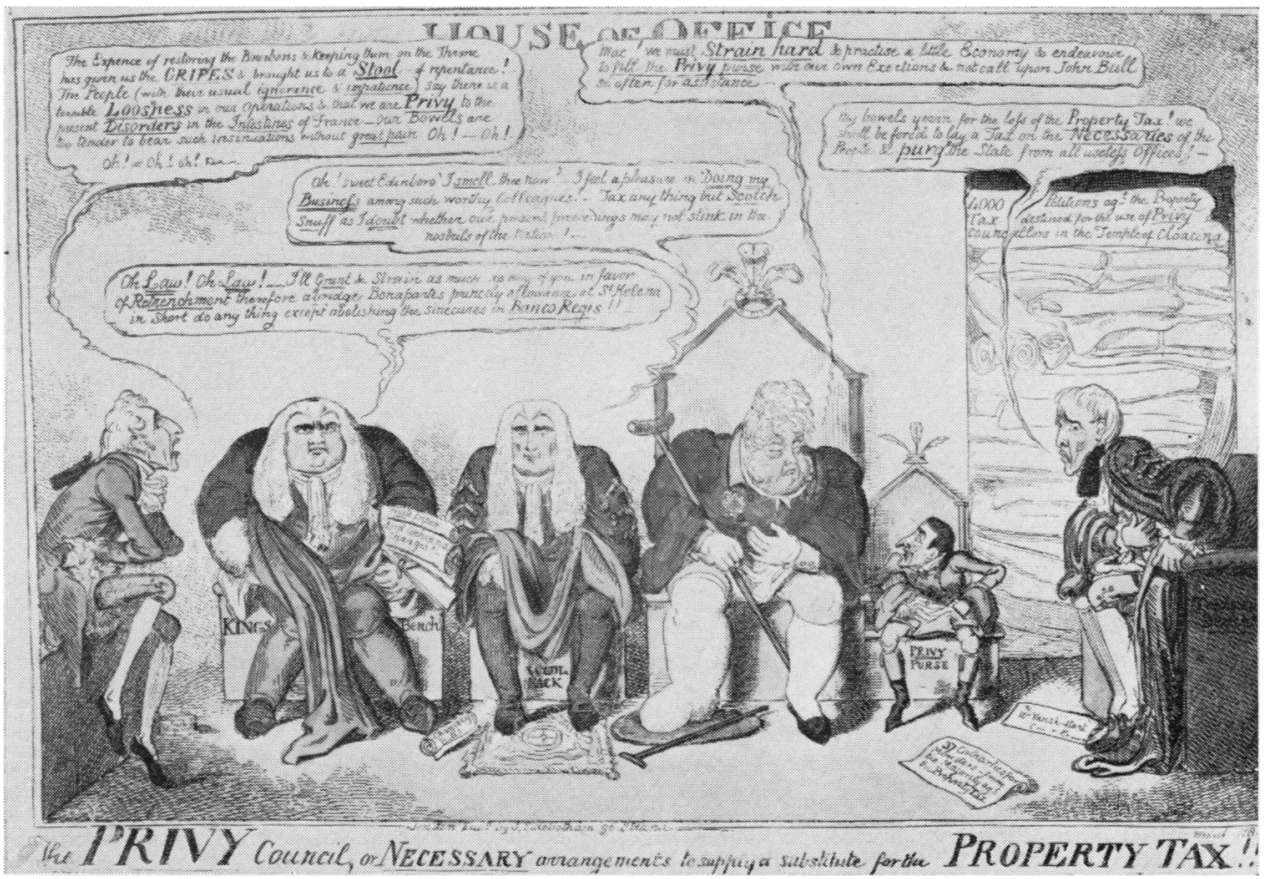

Fig. 5. See legend opposite. 
John Bull and his cartoonists were campaigning for economies and against the heavy taxation; Fig. 6 shows the State physicians bleeding John Bull to death; his doctors, holding lancets, are spilling golden guineas which pour from his veins into the maws of the Royal children, the Prince's Civil List, an oriental dragon, and various extra allowances representing presents, sinecures, etc.; they are opposed only by Brougham with his styptics.

Economy, however, is more easily urged than effected; in another cartoon by Marks (Fig. 7, opposite), John Bull, as a modern Job, is comforted by the Ministers and the Prince Regent with his ermine-covered crutches, who says, "Have patience, John Bull. See how dangerous it is to live off the fat of the land. What heavy affliction it causes me which you need be under no apprehension of enduring. Content yourself with bread and water and you will never suffer the pain of the gout. I must know what is best for you."

Worse was to come, and in 1816 the Princess Charlotte, the Regent's only daughter, was betrothed and married to Prince Leopold, later to become
King of the Belgians.

The expenses of this marriage to the Establishment are shown (in another cartoon, not printed here) as a further heavy burden on poor John Bull, ridden by the young couple. The Prince Regent says, "Push $\stackrel{\text { T }}{+}$ on! Preach economy and when you have got your? money, follow my example"; he is equipped with $\underline{\overline{\underline{\sigma}}}$. orientally ornamented crutches, from Canton and $\frac{\bar{s}}{\bar{D}}$ Pekin, and in the distance is seen the Brighton $\mathbb{\varnothing}$ Pavilion, which by now was absorbing a great» deal of money. A relapse of the gout occurred in $\overrightarrow{0}$ February, 1816, and from this time onwards George:suffered intermittently but regularly, the attacks $\vec{\omega}$ being particularly severe in the years 1818,1821 , $1822,1823,1824,1825,1827$, and 1828 (see the Croker Papers; Knighton, 1838; Fulford, 1933 ; Aspinall, 1938, 1949).

\section{Treatment}

The treatment of gout was just beginning to changeᄋ from the regime prescribed by Sydenham, mainlyherbal mixtures, abstinence, and moderate exercise, $\mathbb{\Phi}_{\mathbb{D}}$

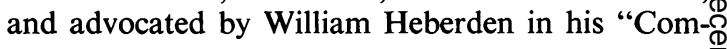

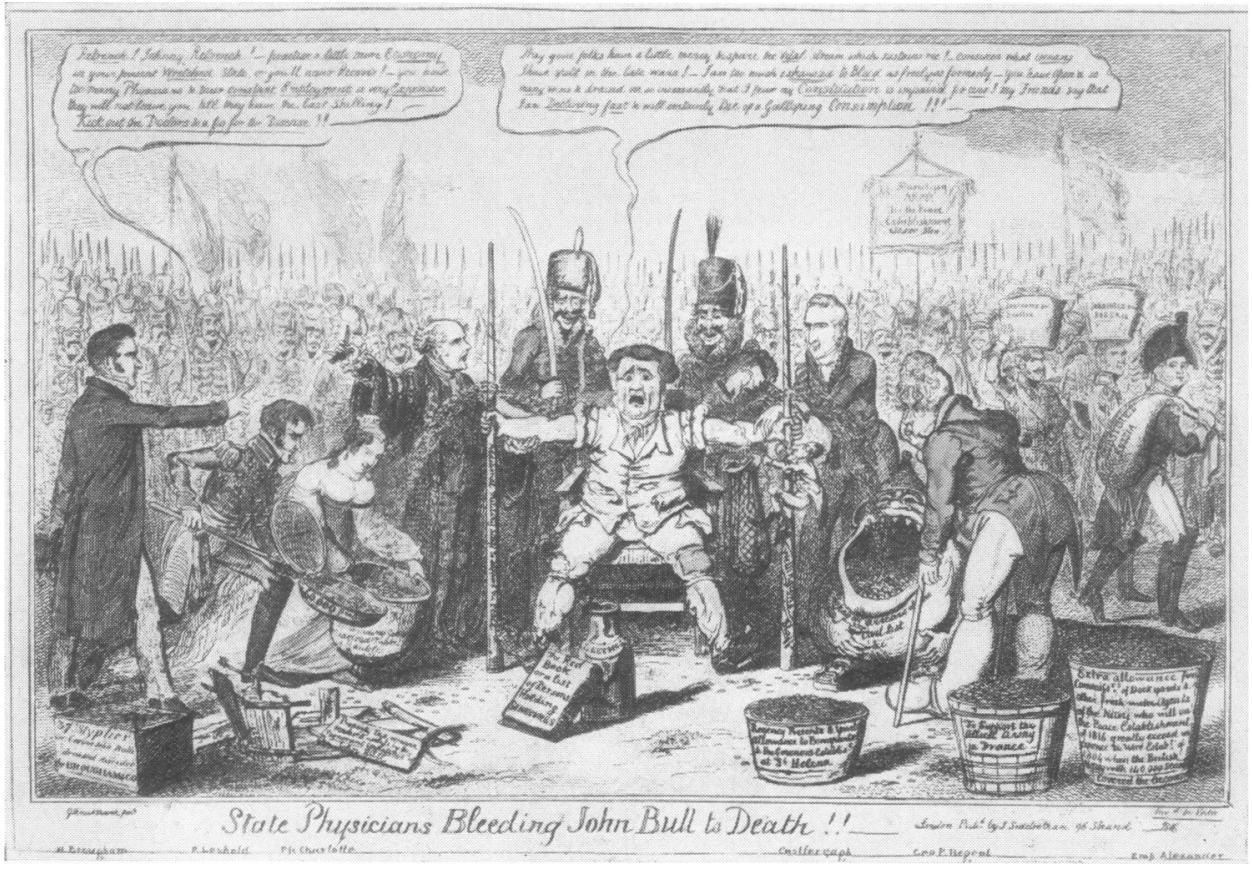

Fig. 6.-STATE PHYSICIANS BLEEDING JOHN BULL to DEATH!!

(B.M. 12756. G. Cruikshank, 1816.)

L. to R.: Henry Brougham, with styptics for curing John Bull ("Economy ... you have too many Physicians \& their constant Employment is very Expensive they will not leave you till they have the last Shilling!-Kick out the Doctors \& a fig for the Disease!!'), Prince Leopold and Princess Charlotte, Vansittart, John Bull, McMahon, Castlereagh, the Prince Regent, with gout and crutches, and the monarchs of Prussia, Austria, and Russia carrying off subsidies.

Phlebotomy (bilateral) is producing two showers of golden guineas. Poor John Bull protests in vain. 


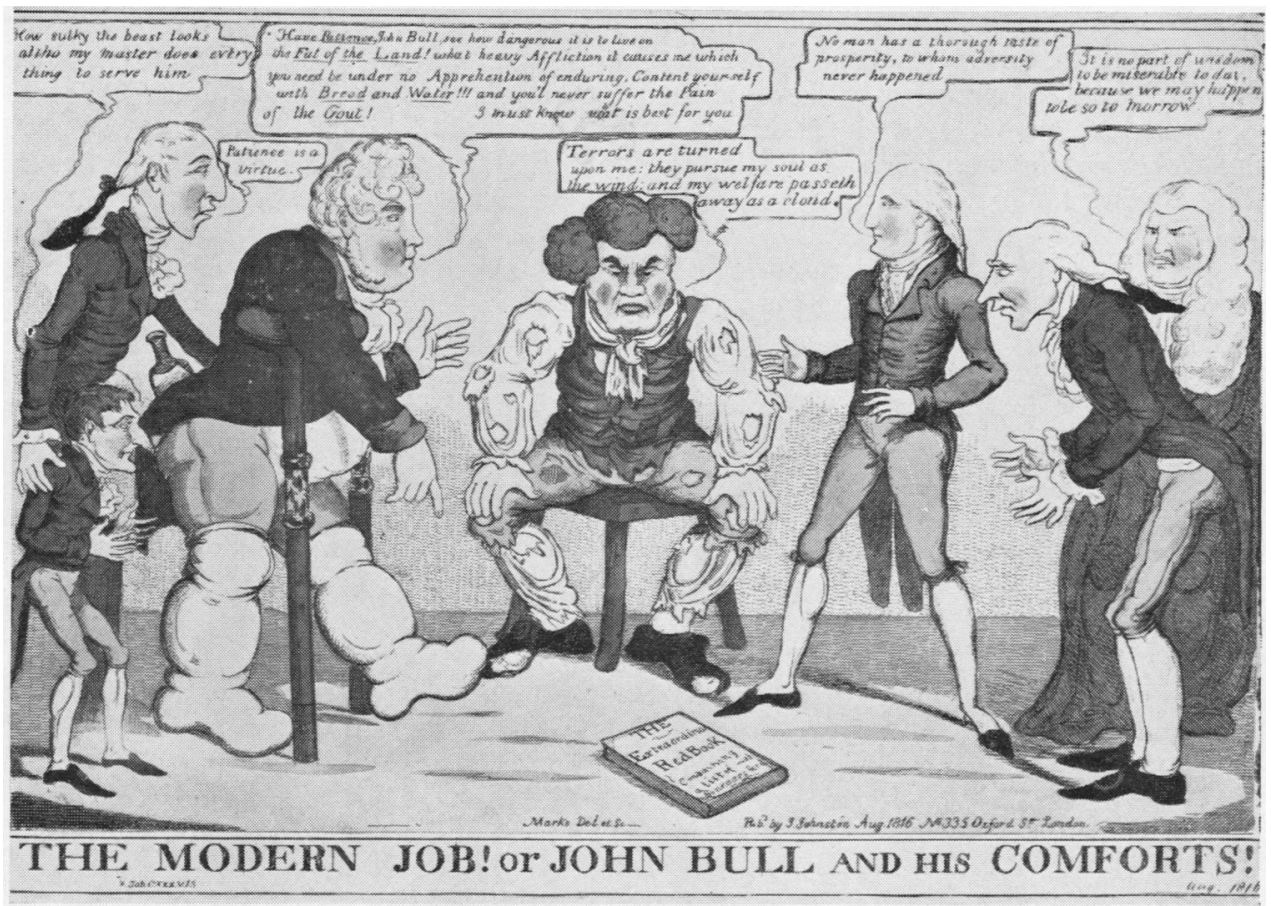

Fig. 7.-THE MODERN JOB! or JOHN BULL \& HIS COMFORTS!

(B.M. 12798. Marks, 1816.)

L. to R.: Liverpool, McMahon, the Prince Regent, John Bull Canning ("No man has a thorough taste of prosperity, to whom adversity never happened"), Sidmouth, and Ellenborough ("It is no part of wisdom to be miserable today because we may happen to be so tomorrow").

mentaries" (1802), as a result of the empirical discovery by a French army officer, Nicholas Husson, of the good effects of Colchicum autumnale. This had been re-introduced in 1763 by Anton Van Störck of the Court of Maria Theresa, but mainly for dropsy and other internal complaints. Husson marketed his famous eau médicinale for gout in the 1770s. A good account of it is given by E. Godden Jones (1810) in a book inscribed to Sir Walter Farquhar, physician to H.R.H. the Prince of Wales. Jones, who had apparently introduced this nostrum to England in 1808, although Ring (1811) alleged that Ronsart had brought twelve bottles to England in 1776 , details its dramatic effect in many patients, including Sir Joseph Banks, the eminent botanist, in 1810, much to the astonishment of Sir Everard Home (who was also the Regent's physician).

Halford himself lost no time, and by the spring of 1810 had given it to twelve patients (Ring, 1811). In 1814 the Regent wrote to Blagden to get two bottles of Husson's liquid from Paris. In this year the active principle, hitherto a closely guarded secret, was identified by Dr. John Want as Colchicum autumnale (Want, 1814) and this was endorsed by Charles Scudamore (1817). Following this identification, the market was flooded with numerous so-called specific cures imitating eau médicinale, and the usual claims were fought out in numerous pamphlets. Edward Jenner (Diary, ed. Hellman, 1931) comments from Cheltenham to John Bull:

"Oh John, thou art surely the greatest of Ninnies,

Why load the French shores with such heaps of thy guineas?

Do prithee thy senses recall.

Know'st thou not, honest John, that all curable ills

Are soon wash'd away by fair Chelta's bright rills?

Come John, then, and try

And thou wilt not deny

That here's the Eau Médicinale."

A letter dated 1816 was printed by Dr. Charles Wilson (Wilson, 1823), who marketed his own specific, requesting some for his Royal Highness, but Halford did not wish to prescribe it without knowing 
its contents. The Prince Regent soon recognized the value of colchicum, and is recorded in 1817 as saying to his doctors, "Gentlemen, I have taken your half measures long enough to please you. Now I shall take colchicum", which (according to Treue, ed. Fawcett, 1958) he did, and was soon relieved.

In 1816 the Prince Regent had to remain at the Pavilion, owing, Halford tells us, to the excessive size of his knees (Aspinall, 1949). Fig. 8, the first of the oriental prints, shows the Regent's large knees and swollen feet in the dragoned splendour of the Royal Pavilion, contrasted with statues of the British Adonis and the Hottentot girl who had been recently on view. This cartoon ostensibly represented an interview with Lord Amhurst, who was off to the Emperor of China bearing presents, but in fact it expressed the ever-present complaint $\stackrel{\frac{}{5}}{3}$ against princely extravagance. The Prince's mother, Queen Charlotte, on the left, is pouring her pin money into McMahon's privy Purse. He is flanked by his favourite, Lady Hertford (with her husband, horned, beside her), and on the other side by Prince? Leopold and his wife, the Princess Charlotte. 흘 Unfortunately, the princess died in childbirth the $\frac{\bar{p}}{\frac{}{\sigma}}$ next year, 1817, which marks perhaps the height $\stackrel{\Phi}{\varrho}$ of the Prince's unpopularity. However, he still@ visited Brighton, although now less frequently. Fig. 9 (see col. pl. facing p. 326) shows him embark-웅 ing thence for the Isle of Wight in the "Royal $\vec{\omega}$ George", saying, "I have been almost suffocated in that infernal bathing machine. Mind my foot!" Nowadays bathing machines are no longer, but they seem to have been quite interesting then.

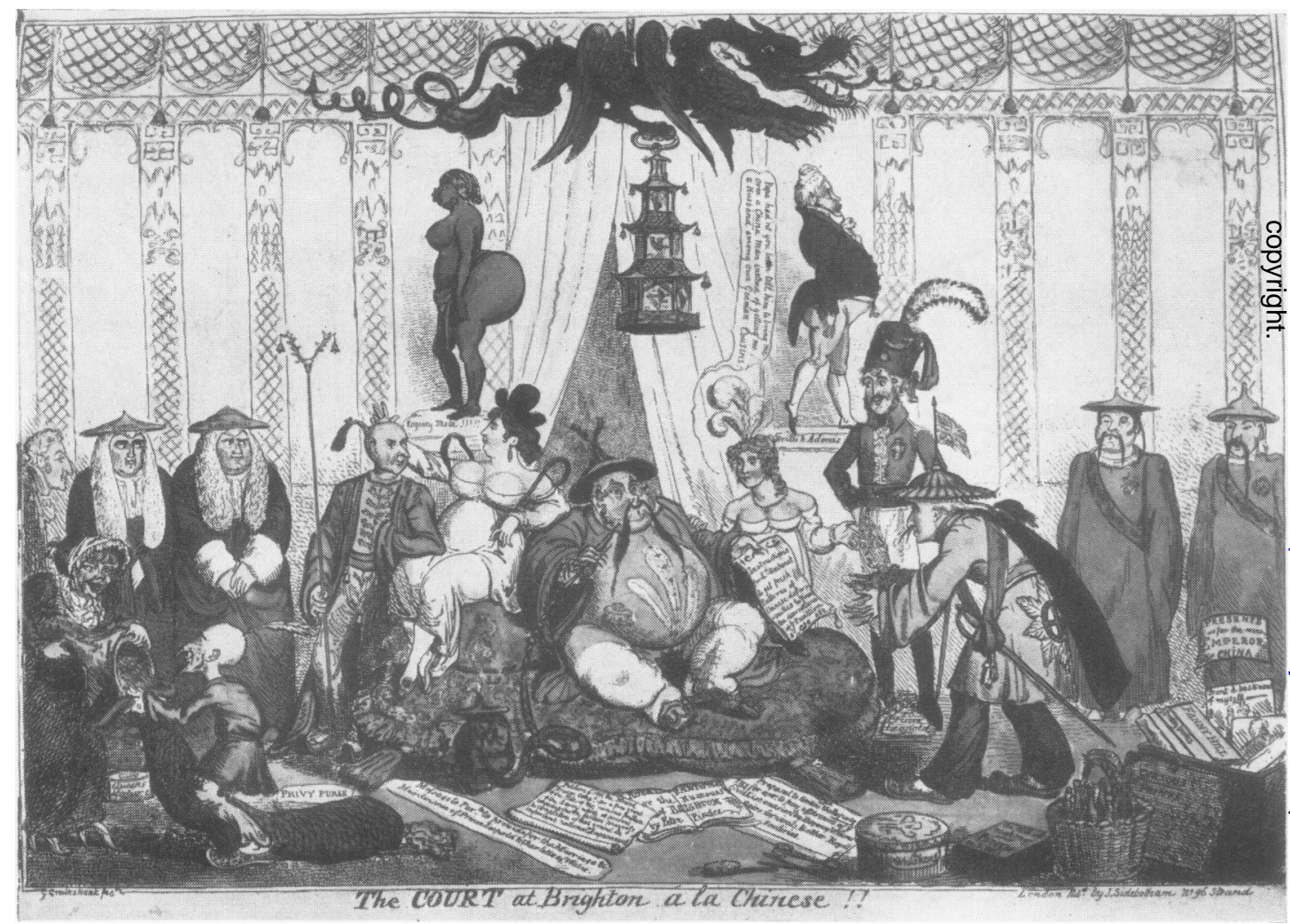

Fig. 8.-The COURT at Brighton á la Chinese!!

(B.M. 12749. Geo. Cruikshank, 1816.)

L. to R.: Castlereagh, Queen Charlotte, pouring “Pin Money, Royal Savings" into McMahon's privy purse, Eldon, Ellenborough Lord Hertford (horned) and his wife, the Prince Regent with gouty legs and split stockings, Princess Charlotte and Prince Leopold, Amhurst, Sligo, and Bloomfield dressed au Chinois. Behind la belle Hottentot is contrasted with the publicized figure of the Prince Regent as the British Adonis.

This, the first of the oriental cartoons, depicting the Royal Pavilion, ostensibly represents the departure of Lord Amhurst with presents for the Emperor of China. 
George was getting so obese that the exercise prescribed by his doctors became difficult, and riding horseback was impossible without the special and ludicrous machinery ridiculed in Fig. 10 (see col. pl. facing p. 336) (see The Times for March, 1816, cited by Sitwell and Barton, 1935). However, he had his excursions, as shown in "a visit to Richmond to alleviate the gout" (Fig. 11); the Duchess of Richmond is nursing his gouty foot and outside the window people are riding on the new fashionable craze, the hobby horse.

In 1818 Queen Charlotte died, and the Duke of York was appointed Keeper of the King's Person, at $£ 10,000$ a year. John Bull was pretty mad at this, as well as at the various expensive hobbies of the Prince (Fig. 12, overleaf).

The Queen's death was shortly followed by that of the old King in 1820. The Princess of Wales (now Queen Caroline) returned home from her Bohemian and well-documented travels to claim her due, and proceedings were set in motion for a divorce on the ground of her behaviour during her sojourn in Europe. This divided and diverted the country. The disgruntled Whigs espoused her cause, seizing this opportunity to attack the King and raking up the past, as far back as the Oatlands sprain, various escapades at Brighton below stairs, sundry amatory adventures, and finally the savage suppression of popular protest at the massacre of Peterloo in 1819. All this made the King's lot not a happy one; Fig. 13 (overleaf) shows "the brightest star in the State" and his various worries, the chief of which was his wife, Queen Caroline, celebrated by Shelley in his anonymous poem, "Oedipus Tyrannus, or Swellfoot the Tyrant"( 1820): "She is returned, Taurina is in Thebes, when Swellfoot wishes she were in Hell!"

The divorce proceedings under the Bill of Pains and Penalties were unsuccessful, but fortunately for George his wife died while he was on a visit to Ireland. This expedition was successful on all counts, and the king experienced popularity such

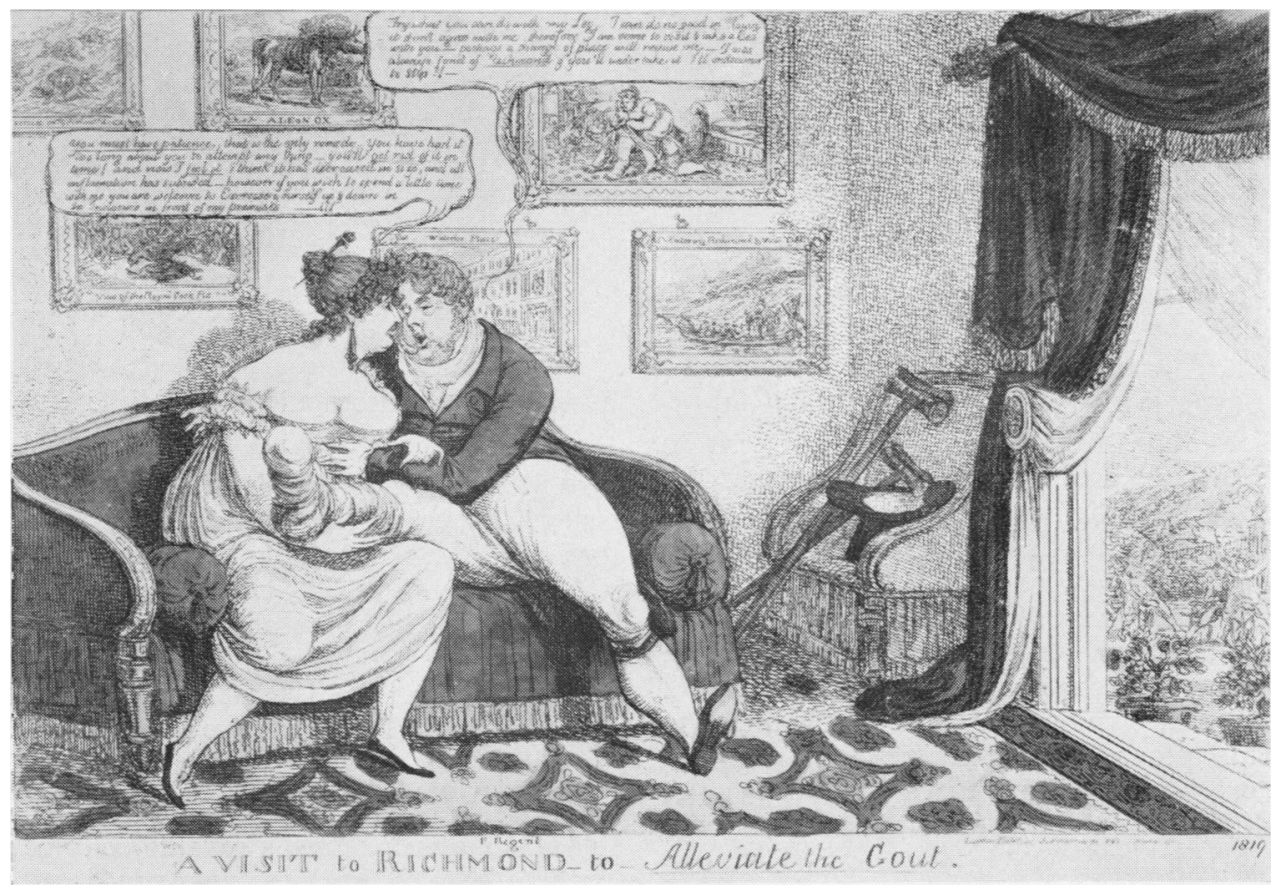

Fig. 11.-A VISIT to RICHMOND-to-Alleviate the Gout.

(B.M. 13234. Williams, 1819.)

The Duchess of Richmond: "You must have patience, that is the only remedy-You have had it too long about you to attempt any thing-you'll get rid of it in time! and now I feel it I think it has decreased in size, and all inflammation has subsided."

In the background are pictures entitled "Exercise on Richmond Hill", "ALEAN OX" (Lennox), "View of the Royal Cock Pitt", "Waterloo Place", "Entering Richmond by Water", and in the foreground an open window with people on hobby horses. 


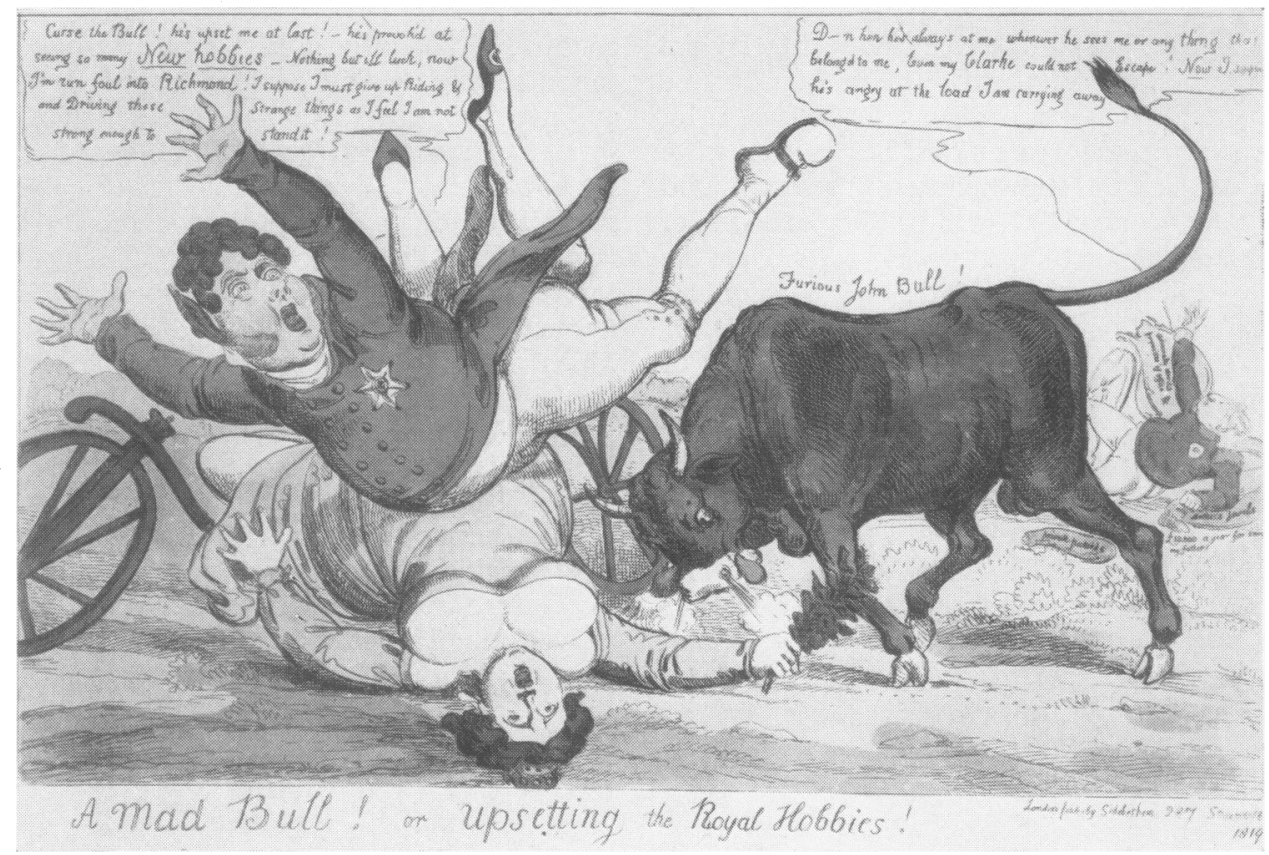

Fig. 12.-A Mad Bull! or Upsetting the Royal Hobbies!

(B.M. 13235. I. R. Cruickshank, 1819.)

L. to R.: The Prince Regent with one gouty foot (and for obscure reasons with an ass's ear) bountifully cushioned by the Duchess of Richmond, both having been spilled by John Bull, as also in the background, the Duke of York, who had recently, since the old Queen's death, been made Guardian of the King's Person (George III) at a salary of $£ 10,000$ a year.

Primitive bicycles were the latest craze, or hobby horse.

as he had not had for many years in England. It was followed the next year (1822) by a visit to Scotland, where one of George's hosts was Sir Walter Scott, accompanied by another Knight, Sir William Curtis, who ran a sea-biscuit factory at Wapping. They were depicted by a cartoonist both in tartans with flesh-coloured pantaloons underneath, according to Sir David Wilkie (Fulford, 1949), together with the Conynghames, horned, father and son, Sidmouth, Lady Conynghame, and Lady Elphinstone. This visit was also a great success, except, it is alleged, that George caught the "Scotch fiddle" or the itch (scabies). "Poo, poo", says Lady Elphinstone, "I may assure you, my Lady Conynghame, it is of no great consequence; indeed it is of so little value in the North that we give it to one another." This, like many other cartoons of this period, was suppressed; whereas 100 years previously the author of such a lampoon was sent to the gallows, now the plates were bought up by the King's agents, which made quite good business for unscrupulous publishers (George,, $\overrightarrow{\vec{O}}$
1935-).

In 1821 a sebaceous wart had been removed, by Astley Cooper and Benjamin Brodie, from the roya forehead. "Next morning when I went, the Kingowas on the sofa. His great toe was red with gout and his head had lost all its soreness" (Cooper, 1843). He was bled by Knighton, who was his Private Secretary and what might be called the family doctor. Post-operative gout was well recognized then.

After this, occasional attacks of gout occurred. In 1823 an attack caused a royal levée to be put off, and in a contemporary cartoon, gout is personified 0 holding up the crowds in front of Buckingham Palace-a gruesome half-human, half dragon-like् creature.

From 1824 onwards, the King took a back place and, with lessening austerity and greater prosperity; was regarded in a more kindly light by the public, $\frac{\square}{\vec{T}}$ 


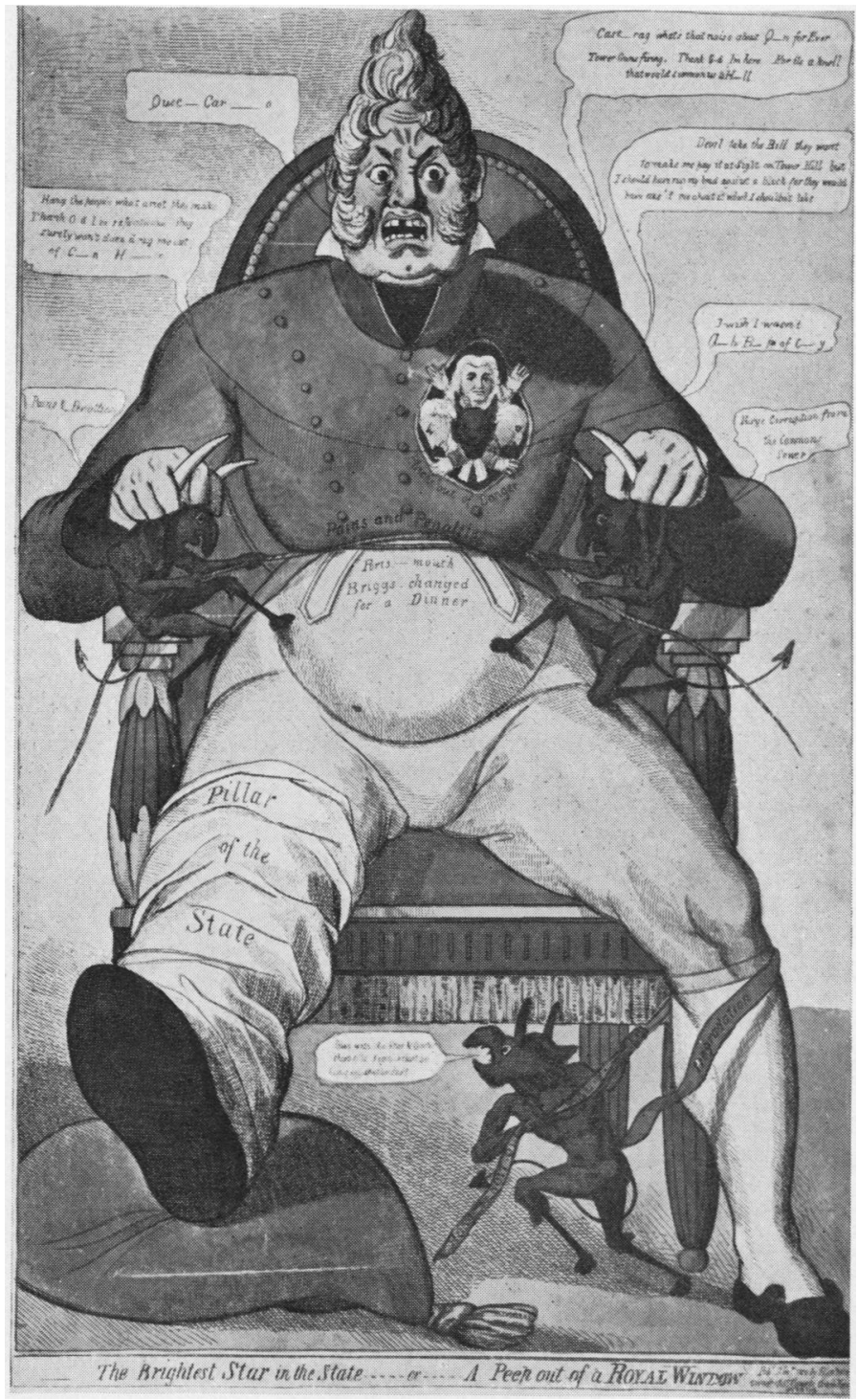

Fig. 13. - The Brightest Star in the State ... or ... A Peep out of a ROYAL WINDOW.

(B.M. 13987. November, 1820.)

The window in the Royal breast contains Eldon (on top), Castlereagh (left), and ? Liverpool (? the Archbishop of Canterbury), right.

George is in torment at the news of his wife's homecoming, with one pillar of the State gouty and the other degartered by a revolutionary devil.

whose company he fled, solacing his gout with colchicum and himself with Lady Conynghame and cherry brandy. In 1826 he is shown in retreat at the Royal cottage in Windsor Park, fishing with Lady Conynghame (Fig. 14, overleaf), the oriental trappings of his summer house contrasting vividly with Windsor Castle in the background. He was so sensitive to public opinion that, as Lady Shelley remarked, "This cartoon alone stopped him fishing." The last 3 years of his life were spent in 
seclusion at Windsor with intermittent gout and dropsy, due, Halford thought, to heart disease. In 1827 he paid a visit to Brighton, where he held a Privy Council despite an attack of gout and "little or no use of my poor limbs", as he wrote to Sir William Knighton, his personal doctor and secretary.

In 1828 (Fig. 15) we see him discarding the Whigs and bringing in Wellington as Prime Minister. Gout is shown always in the leg but never visibly in the hands, although in 1828 he had such severe gout in the right hand that he was scarce able to hold his pen, and was so feeble that he had to be carried to and from his carriage (Croker Papers).

The great public issue at this time was the dispute on the subject of Catholic Emancipation, favoured by the Whigs but violently opposed by the old Tories-the Duke of Cumberland and the ghost of George III, as well as George IV. Wellington recognized, however, that emancipation was inevitable and that we should lose Ireland unless the Catholics were given liberty to hold civil and political appointments. This was shown allegorically in the topical form of Burke and Hare
(Peel and Wellington) burking poor old Mrs. Constitution, with a Jesuit priest in the guise of Dr. Knox of Edinburgh waiting in the back-on ground.

Fig. 16 (overleaf) epitomizes the situation; Wel $\stackrel{\overrightarrow{\vec{\rho}}}{\vec{P}}$ lington is persuading the now very sick King of theo necessity of Catholic Emancipation. He is featuredo as the new doctor, taking the royal pulse and holding $\frac{\bar{s}}{\vec{b}}$ in his right hand a doctor's cane with its vinaigrette,$\stackrel{\mathbb{\Omega}}{\Omega}$ "A great deal of fever remaining, considerablen irritation to be got rid of, then the pill will works well. Take plenty of punch by way of alterative. The Catholic pill is on the table. The King replies, $\vec{\omega}$ "O, Doctor, Doctor! Your remedies are worse than the disease-they are undermining the Con- $\frac{0}{2}$ stitution." It was indeed undermined: it had taken a lot of punishment. As Huish (1830) put it: "The poisonous drugs of the cup of pleasurect gnawed his innards." Brodie had punctured his legs; what was hoped for was "a revulsion oro translation of the gout" (Lancet, 1830) from theheart to the extremities, but the royal patient diedo of what Halford had diagnosed as heart disease, $\overparen{\mathbb{R}}$ on June 26,1830 , at the age of 68 , attended by

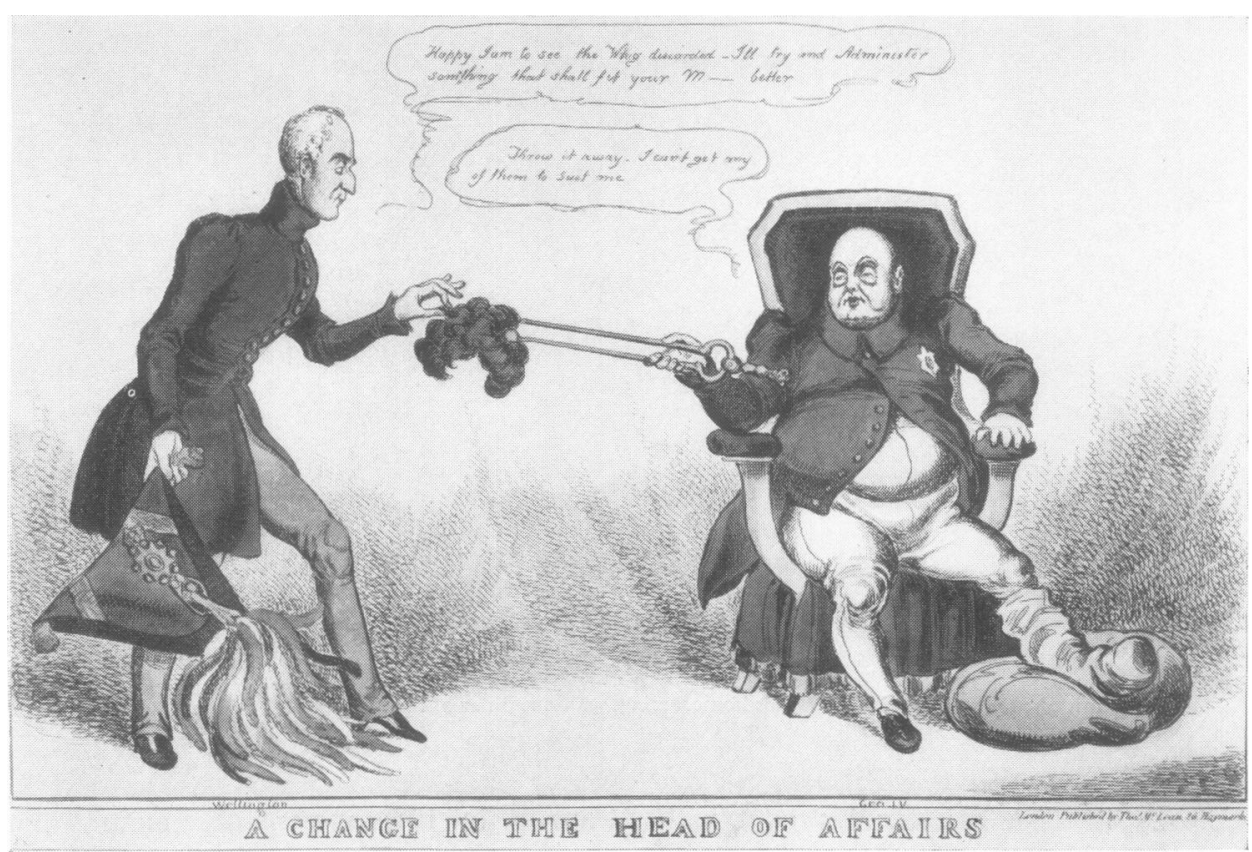

Fig. 15.-A CHANGE IN THE HEAD OF AFFAIRS.

(B.M. 15498. “Paul Pry" (Wm. Heath), January, 1828.)

Discarding the Whig (Goderich) and installing Wellington. 


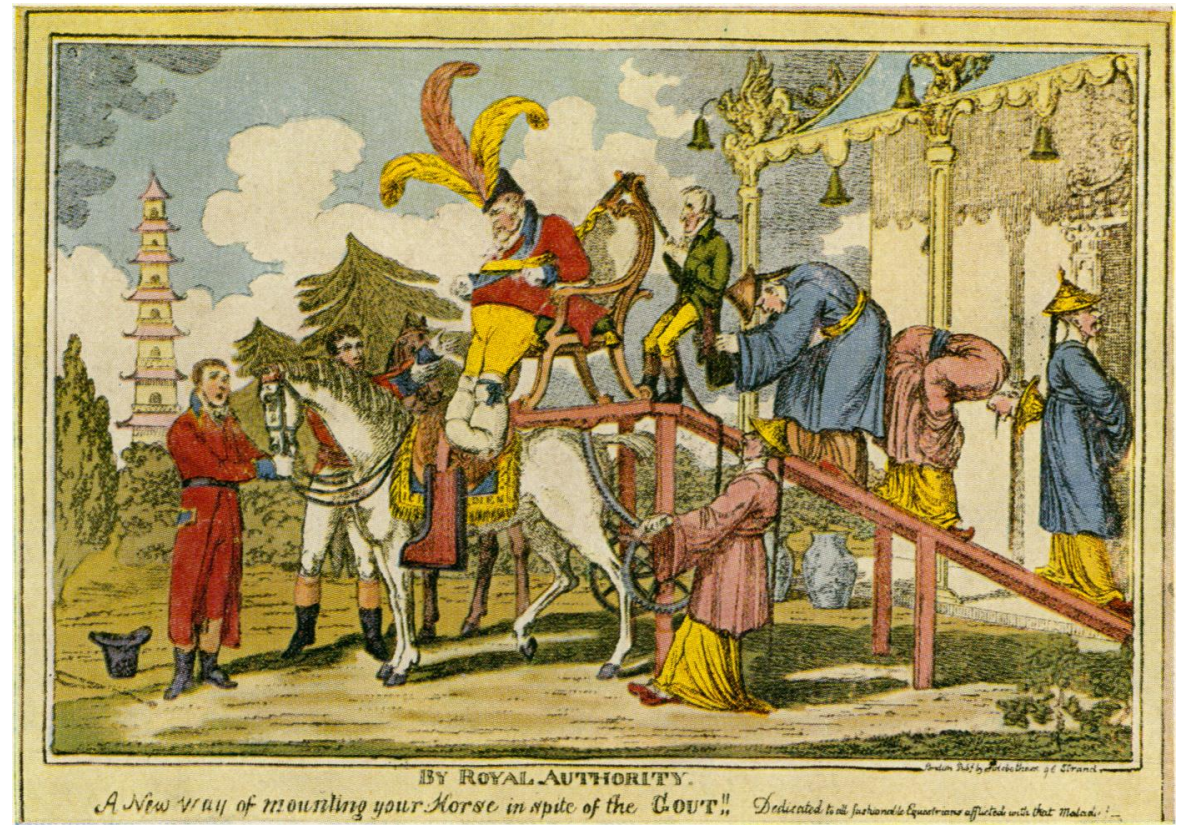

Fig. 10.-BY ROYAL AUTHORITY.

A New way of mounting your Horse in spite of the GOUT!! Dedicated to all fashionable Equestrians afflicted with that Malady.

(G. Cruikshank, c. 1816. See The Times, March, 1816, cit. Sitwell and Barton, 1935, p. 227.) Photograph by permission of the Royal Pavilion Committee.

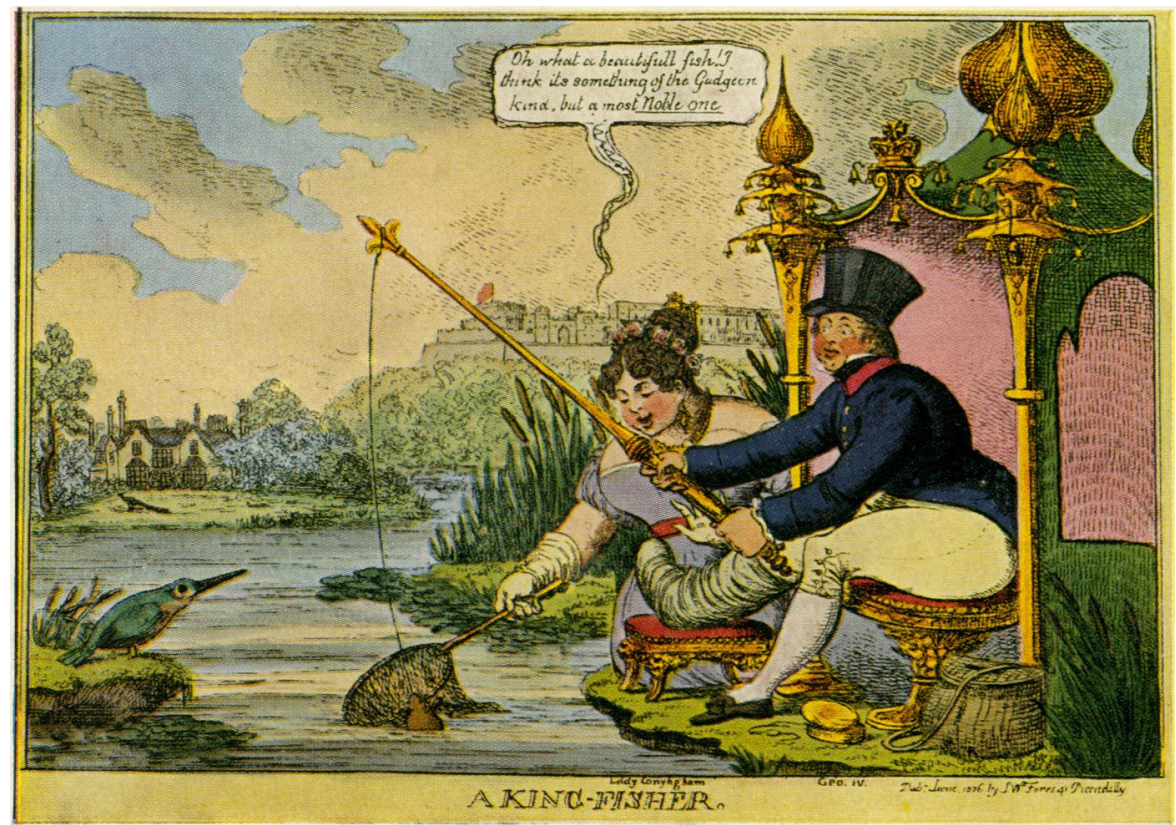

Fig. 14.-A KING-FISHER.

(B.M. 15137. Williams, June, 1826.)

George IV and Lady Conyngham, who solaced his last years, fishing in Virginia Water near Windsor and Royal Lodge.

[ facing p. 336 


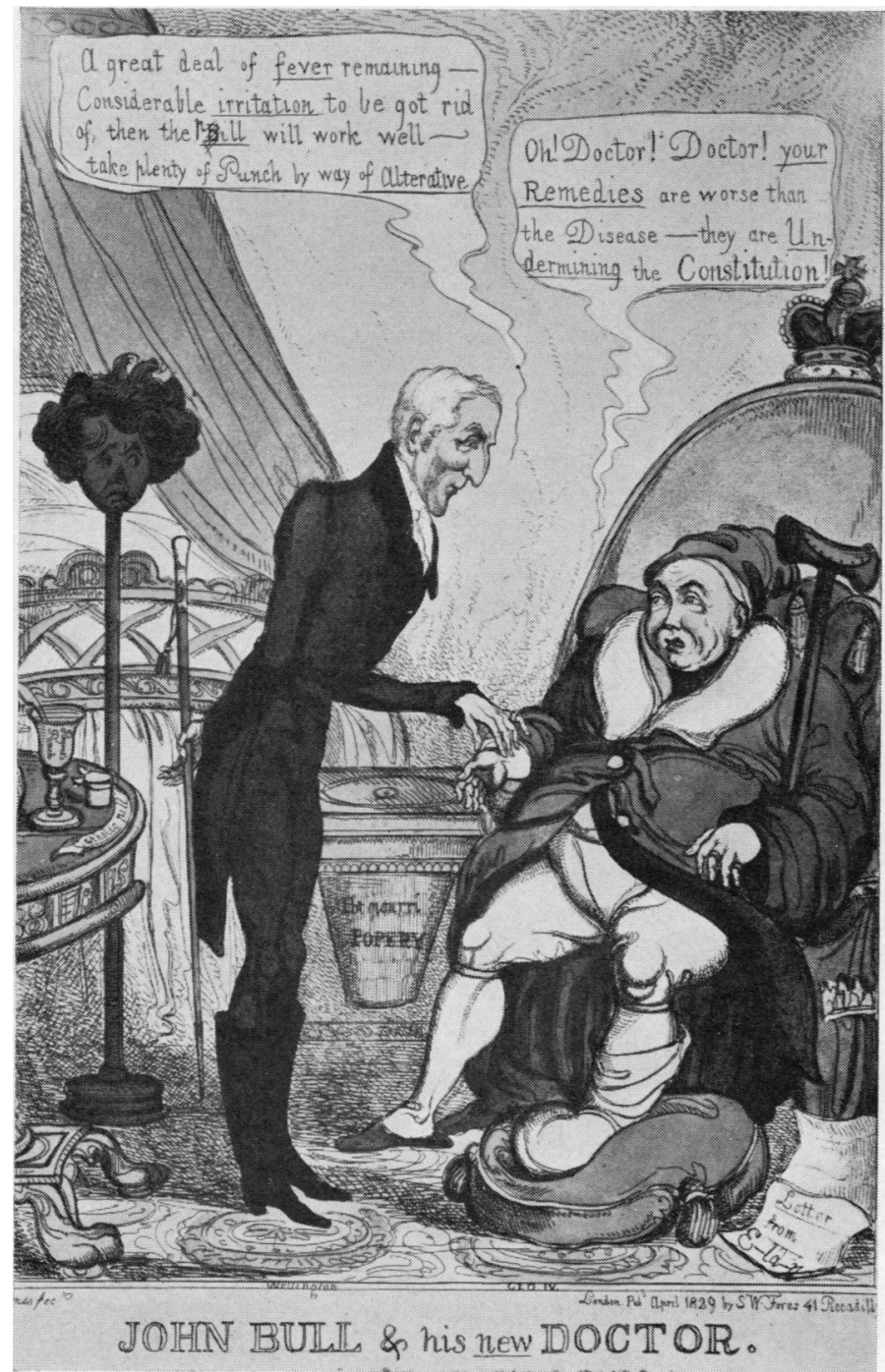

Fig. 16.-JOHN BULL \& his new DOCTOR.

(B.M. 15710. T. Jones, April, 1829.)

Wellington, now aged 60 ("A great deal of fever remaining-Considerable irritation to be got rid of, then the pill wili work well-take plenty of Punch by way of Alterative"), and George IV, aged 67, represented as John Bull, because of his opposition (with Eldon, York, and Cumberland) to Catholic emancipation ("Oh! Doctor! Doctor! your Remedies are worse than the Disease-they are Undermining the Constitution!').

Note the physician's cane with its vinaigrette.

Drs Halford, Knighton, Tierney, and Brodie. The autopsy, done by Sir Astley Cooper and reported in extenso as the culmination of Wakley's campaign against the physicians' bulletins, showed cardiomegaly, aortic stenosis, a large urinary calculus, a ruptured blood vessel in the stomach, and cirrhosis of the liver (Lancet, 1830). Then, as now, the presence of gout was not thought worth mentioning -and indeed the king had lived to the age of 68 exposed to numerous hazards, in reasonably good health. He was, as Arthur Bryant (1950) writes, "at once a national scandal, a national disaster, a national achievement, and a national entertainment."

Altogether, throughout history, many of the prime movers have been gouty: gout affects more rich than poor, more wise men than fools, and it is 
interesting to speculate with Orowan (1955) whether uric acid has fulfilled the same role in the evolution of man, as coffee and the methyl purines have played since they were introduced to Western civilization in the age of colonial development. As Orowan asks, "Could the primacy of primates be due to their loss of uricase?" Although George IV's death owed little to his gout, his life was determined by the hyperuricaemia which lay behind it, and so to some extent during this highly critical period was our Island history.

This highly-compressed case report may perhaps be of interest, not only as an illustration of medical attitudes during a crucial period of scientific development, but also to students of the perennial controversy about the role of the individual (and his milieu interieur) in the formation of that most statistical of all processes-history.

I am indebted to Mr. P. J. Fiske, who took the photographs, and to the staff of the Print Room at the British Museum for their help, as well as to Mr. L. M. Payne of the Royal College of Physicians and to the Curator and the Committee of the Royal Pavilion, Brighton, for permission to reproduce Fig. 8. The Wellcome Trust has kindly made a grant to cover the cost of the coloured plates.

\section{REFERENCES}

Aspinall, A. (ed.) (1938). "Letters of George IV, 1812-1830." University Press, Cambridge.

- (ed.) (1949). "Letters of the Princess Charlotte, 1811-1817." Home and Van Thal, London.

Bryant, A. (1950). "The Age of Elegance, 1812-1822," p. 109. Collins, London.

Buckingham and Chandos, Duke of (1856). "Memoirs of the Court of England, during the Regency, 1811-1820," vol. 1, p. 162. Hurst and Blackett, London.

Byron, G. G. N. (1905). "The Poetical Works of Lord Byron," ed. E. H. Coleridge. Murray, London.

Castle, Egerton (ed.) (1896). "The Jerningham Letters, 1780-1843," vol. 2, p. 382. Bentley, London.

Cooper, B. B. (1843). " "The Life of Sir Astley Cooper." Parker, London.

Forbes, M. (1793). "A Treatise upon Gravel and upon Gout." London.

Fulford, R. (1933). "Royal Dukes: the Father and Uncles of Queen Victoria,” p. 301. Duckworth, London.

- (1949). "George the Fourth," 2nd ed. Duckworth, London.

Garrod, A. B. (1848). Med.-chir. Trans., 31, 83.

George, M. D. (1935-). "Catalogue of Political and Personal Satires." British Museum.

Gower, F. Leveson (ed.) (1894). "Letters of Harriet, Countess Granville, 1810-1845." Longmans, London.
Gower, G. Leveson (1916). "Lord Granville Leveson Gower (First Earl Granville), Private Correspondence, 1781-1821," ed. C. Granville. Murray $\frac{\square}{w}$ London.

Haygarth, J. (1805). “A Clinical History of Diseases. $\stackrel{\overrightarrow{7}}{\stackrel{\vec{D}}{+}}$ Cadell and Davies, London.

Heberden, W. (1802). "Commentarii de morborun historia et curatione." Payne, London.

Hellman, C. D. (ed.) (1931). “An Unpublished Diary $1810-1812$, by E. Jenner." Ann. med. Hist.尺 n.s. 3, 412 .

Huish, R. (1830). "Memoirs of George IV." Kelly, London.

Jennings, L. J. (ed.) (1884). “The Croker Papers," vol. 1, p. 359. Murray, London.

Jones, E. G. (1810). "An Account of the Effects of? the Eau . . . medicinale d'Husson in the Gout, 2nd ed. White and Cochrane, London.

Knighton, D. (1838). "Memoirs of Sir Williamp Knighton." Bentley, London.

Lancet (1830). Vol. 2, pp. 295, 340, 386, 425, 457, 497 N $546,550,578,614$.

Law, E. (Lord Ellenborough) (1881). "A PoliticaL Diary 1828-1830," ed. Lord Colchester, vol. 2ㅁ p. 323. Bentley, London.

Misaurus, P. (pseudonym) (1720). "The Honour $0 \stackrel{\mathbb{Q}}{7}$ the Gout." Roberts, London.

Munk, W. (1895). "The Life of Sir Henry Halford市 Bart." Longmans, Green, London.

Orowan, E. (1955). Nature (Lond.), 175, 683.

Ring, J. (1811). "A Treatise on the Gout."

London.
Scheele, C. W. (1776). Kongl. Vetenskaps-Acad. Handl. $37,327$.

_ (1786). "The Chemical Essays,' ed. T. Beddoes Murray, London.

(1788-89). "Opuscula Chemica et Physica," Latin version by Schaefer, ed. E. B. G. Hebenstreitô Leipzig.

Scudamore, C. (1817). "A Treatise on the Nature and Cure of Gout and Rheumatism," 2nd ed. London?

Shelley, Lady F. (1913). "The Diary of Frances, Lady Shelley, 1818-1873,"'ed. R. Edgcumbe, vol.2, p. 206ळ

Shelley, P. B. (1820). "Oedipus tyrannus, or Swellfoō the Tyrant."

Sitwell, O., and Barton, M. (1935). "Brighton. Faber and Faber, London.

Storck, A. (1763). "Libellus: de colchico autumnale."ㅇ Vienna. (English version published in London? 1764.)

Strachey, L., and Fulford, R. (1938). "The Greville Memoirs, 1814-1860," vol. 2, p. 7. Macmillan 요 London. Sydenham, T. (1749). "The Entire Works," trans
J. Swan, 2nd ed. Cave, London.

Treue, W. (1958). “Doctor at Court," trans. F. Fawcetto Weidenfeld and Nicolson, London.

Want, J. (1814). Med. and phys. J., 32, 77.

Wilson, C. (1823). "Observations on Gout an Rheumatism," 3rd ed. Underwood, London.

Wollaston, W. H. (1797). Phil. Trans., 87, 386. 